\title{
The problem of depth in geology When pressure does not translate into depth
}

\author{
Journal Article \\ Author(s): \\ Moulas, E.; Podladchikov, Yuri Y.; Aranovich, L.Y.; Kostopoulos, D. \\ Publication date: \\ 2013-11 \\ Permanent link: \\ https://doi.org/10.3929/ethz-b-000074972 \\ Rights / license: \\ In Copyright - Non-Commercial Use Permitted \\ Originally published in: \\ Petrology 21(6), https://doi.org/10.1134/S0869591113060052
}




\title{
The Problem of Depth in Geology: When Pressure Does Not Translate into Depth ${ }^{1}$
}

\author{
E. Moulas ${ }^{a}$, Y. Y. Podladchikov ${ }^{b}$, L. Ya. Aranovich ${ }^{c, d}$, and D. Kostopoulos ${ }^{e}$ \\ ${ }^{a}$ Department of Earth Sciences, ETH-Zürich, Sonneggstrasse 5, 8092 Zürich, Switzerland \\ ${ }^{b}$ Institute of Earth Sciences, University of Lausanne, CH-1015 Lausanne, Switzerland \\ ${ }^{c}$ Institute of the Geology of Ore Deposits, Petrography, Mineralogy, and Geochemistry, IGEM, Russian Academy of Sciences, \\ Staromonetnyi per., 35, Moscow, 109017 Russia \\ ${ }^{d}$ Department of Geology, University of Johannesburg, Auckland Park, Johannesburg 2006, South Africa \\ ${ }^{e}$ Faculty of Geology and Geoenvironment, National and Kapodistrian University of Athens, 15784 Greece \\ e-mail:evangelos.moulas@erdw.ethz.ch; lyaronov@igem.ru \\ Received March 24, 2013
}

\begin{abstract}
We review published evidence that rocks can develop, sustain and record significant pressure deviations from lithostatic values. Spectroscopic studies at room pressure and temperature $(P-T)$ reveal that in situ pressure variations in minerals can reach GPa levels. Rise of confined pressure leads to higher amplitude of these variations documented by the preservation of $\alpha$-quartz incipiently amorphized under pressure (IAUP quartz), which requires over $12 \mathrm{GPa}$ pressure variations at the grain scale. Formation of coesite in rock-deformation experiments at lower than expected confined pressures confirmed the presence of GPalevel pressure variations at elevated temperatures and pressures within deforming and reacting multi-mineral and polycrystalline rock samples. Whiteschists containing garnet porphyroblasts formed during prograde metamorphism that host quartz inclusions in their cores and coesite inclusions in their rims imply preservation of large differences in pressure at elevated pressure and temperature. Formation and preservation of coherent cryptoperthite exsolution lamellae in natural alkali feldspar provides direct evidence for grain-scale, $\mathrm{GPa}-$ level stress variations at $680^{\circ} \mathrm{C}$ at geologic time scales from peak to ambient $P$ - $T$ conditions. Similarly, but in a more indirect way, the universally accepted 'pressure-vessel' model to explain preservation of coesite, diamond and other ultra-high-pressure indicators requires $\mathrm{GPa}$-level pressure differences between the inclusion and the host during decompression at temperatures sufficiently high for these minerals to transform into their lower pressure polymorphs even at laboratory time scales. A variety of mechanisms can explain the formation and preservation of pressure variations at various length scales. These mechanisms may double the pressure value compared to the lithostatic in compressional settings, and pressures up to two times the lithostatic value were estimated under special mechanical conditions. We conclude, based on these considerations, that geodynamic scenarios involving very deep subduction processes with subsequent very rapid exhumation from a great depth must be viewed with due caution when one seeks to explain the presence of microscopic ultrahigh-pressure mineralogical indicators in rocks. Non-lithostatic interpretation of high-pressure indicators may potentially resolve long-lasting geological conundrums.
\end{abstract}

DOI: $10.1134 / \mathrm{S} 0869591113060052$

\section{INTRODUCTION}

Since the pioneering publications by Eskola (1929) and Korzhinskii $(1940 ; 1959)$ depth has become one of the major parameters to be considered in hard-rock geology. Korzhinskii (1940) based his "facies of depth" systematics on the succession of carbonation reactions in Ca-rich rocks. In the 1960's, pressure in metamorphic environments was constrained qualitatively through applying simple mineral equilibria that define stability of a few major index minerals (e.g., Ernst, 1963). After geothermobarometry was first introduced into petrology by Perchuk $(1967 ; 1970)$, the quantitative determination of pressure-tempera-

\footnotetext{
${ }^{1}$ The article is published in the original.
}

ture conditions has become routine in metamorphic studies. Conventionally, pressure and depth are thought of as synonymous due to the application of Archimedes' formula as a first-order approximation for the calculation of depth at the base of a rock column using pressure as input. This formula was derived from the force balance for static fluids in the gravity field and relates pressure with depth via:

$$
P=\rho g h,
$$

where $P$ is the pressure, $\rho$ is the density, $g$ is the acceleration of gravity and $h$ is the height of the hydrostatic column (depth). In deforming regions of the lithosphere (at any length scale), stresses that develop due to deformation will have an additional effect on the value of pressure. In that case, we would have deviations 


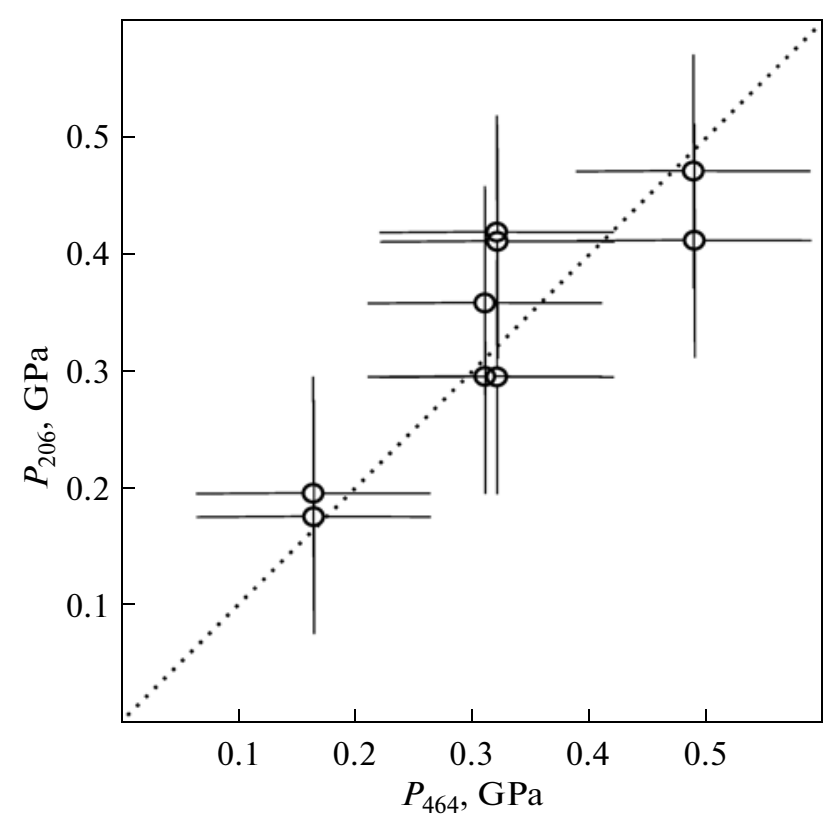

Fig. 1. Pressure dependence of the Raman spectra of quartz used to evaluate residual pressures from quartz inclusions in garnet from the Greek Rhodope. The quartz inclusions are ca $10 \mu \mathrm{m}$ in diameter and are enclosed in garnets with a radius of ca $0.5 \mathrm{~mm}$. The shift of the two major Raman bands (206 and $464 \mathrm{~cm}^{-1}$ ) relative to an unstressed quartz single crystal is used to estimate pressure $\left(P_{464}\right.$ and $\left.P_{206}\right)$. The calibration used is after Schmidt and Ziemann (2000). Note that the maximum pressure recorded in this sample (ca $0.5 \mathrm{GPa}$ ) roughly corresponds to the pressure of a rock situated in the middle crust if Eq. (1) is used.

from the lithostatic pressure formula Eq. (1) that can be positive (overpressure) or negative (under-pressure). The magnitude of these deviations is crucial if depth is estimated from pressure and for this reason quantitative studies and different mechanical scenarios have to be considered.

In this paper we review published data on the pressure variations recorded by metamorphic rocks. We subsequently present possible mechanisms that can be responsible for the formation and preservation of pressure variations in rocks and discuss the feasibility of predicting burial depth from pressure estimates.

\section{PRESSURE INFORMATION FROM MINERAL ASSEMBLAGES}

High-pressure mineral polymorphs like diamond and coesite are used as diagnostic features for the former existence of ultrahigh-pressure (UHP) mineral assemblages. These polymorphs are commonly found as inclusions in other minerals such as zircon, garnet and clinopyroxene (e.g. Sobolev and Shatsky, 1990; Chopin and Sobolev, 1995). The development of a pressure differential between inclusion and host has been used in fluid inclusion studies (e.g., Roedder and
Kopp, 1975; Yamamoto and Kagi, 2008), and also to explain the preservation of coesite in metamorphic rocks (e.g. Gillet et al., 1984; Smith, 1984; Van der Molen and Van Roermund, 1986). In certain cases, high residual pressures (up to 1-2 GPa) are still present in rocks at ambient conditions (e.g. Parkinson and Katayama, 1999; Parkinson, 2000; Ye et al., 2001; Nasdala et al., 2003; Enami et al., 2007; Howell et al., 2010). By using the pressure-dependent shift in the Raman spectra of coesite Parkinson (2000) was able to show that those coesite inclusions that did not display rupturing of the host garnet may be still subject to confining pressure of around $2 \mathrm{GPa}$. Employing the same method, Sobolev et al. (2000) estimated a confining pressure of $3.5 \mathrm{GPa}$ for coesite inclusions in diamonds. Enami et al. (2007) demonstrated the existence of residual pressure by considering the pressure dependence of the Raman spectra of quartz (e.g., Fig. 1). Apart from the pressure variations documented for inclusions in garnet, the formation of chemically zoned plagioclase around kyanite has been used by Tajemmanová et al. (2013; submitted) to explain the preservation of kyanite at low pressures and high temperatures, outside its stability field. The reason for these high residual pressures is that the host mineral acts as a "pressure vessel" inhibiting decompression of the inclusion (e.g., Chopin, 2003). The common assumption in such models is that the host phase had the same pressure and temperature $(P-T)$ as the included phase at the time of enclosure.

Residual pressures are preserved not only during ascent and exhumation, as is commonly assumed. Parkinson (2000) documented the preservation of quartz crystals in garnet cores in a whiteschist from the Kokchetav massif (Kazakhstan) and of coesite crystals in their rims during peak metamorphism at UHP conditions (Fig. 2). Robin (1974) demonstrated that the stresses developed during the formation of coherent exsolution within cryptoperthitic alkali feldspars at approximately $680^{\circ} \mathrm{C}$ are of the order of GPa. These stresses were preserved after the decompression and cooling of the samples as revealed by TEM studies (Robin, 1974).

Palmeri et al. (2009) reported the finding of $\alpha$-quartz incipiently amorphized under pressure (IAUP quartz) as inclusion in omphacite from eclogites of Lanterman Range, Antarctica, where regional highpressure estimates were of the order of $3.3 \mathrm{GPa}$ (Palmeri et al., 2007). The presence of IAUP quartz suggested a pressure range for the inclusion between 15 and $32 \mathrm{GPa}$ (Palmeri et al., 2009; Godard et al., 2011).

Pressure variations are not specific only for inclusion-host relationships. Coesite has been experimentally produced in the intergranular region of deforming quartzite (Fig. 3) at confining pressures below its stability field under tri-axial stress conditions (confining pressure $\sigma_{2}=\sigma_{3} \approx 1.2 \mathrm{GPa}, T=973 \mathrm{~K}$; Hirth and Tullis, 1994). 
(a)

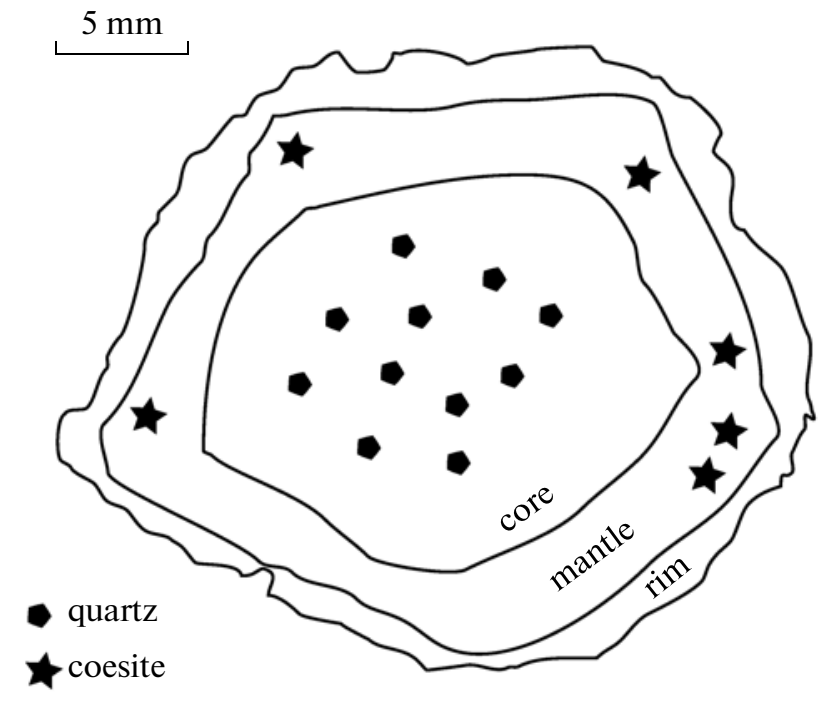

(b)

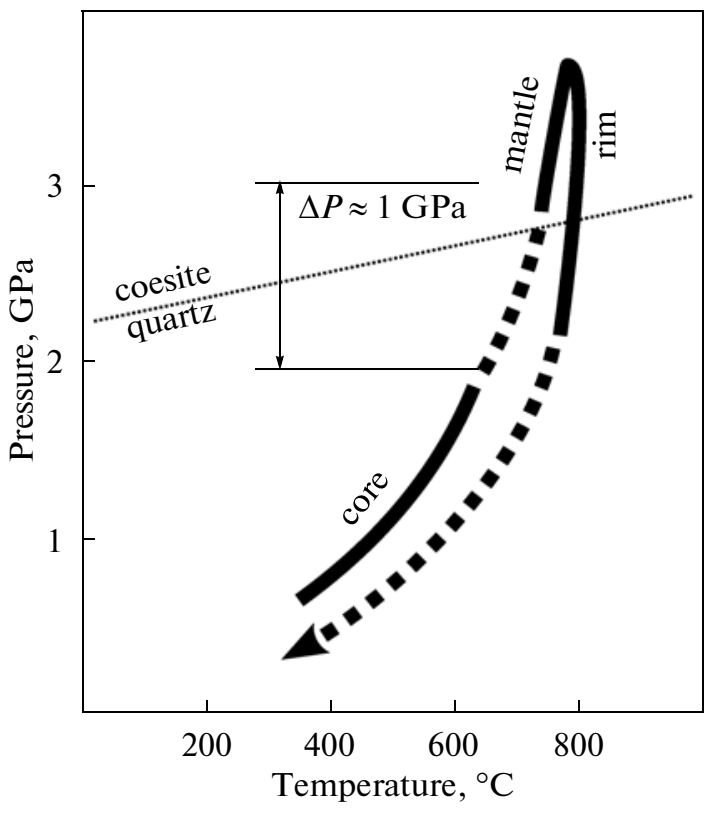

Fig. 2. (a) Sketch of garnet porphyroblast from a Kokchetav Massif whiteschist, showing the distribution of quartz and coesite inclusions in different growth zones (after Parkinson 2000, simplified). (b) $P$ - $T$ estimates by Parkinson (2000) place the formation of garnet core at $P<1 \mathrm{GPa}$ and $T=380^{\circ} \mathrm{C}$. Higher $P$ - $T$ conditions were estimated for the coesite-bearing garnet rims $(P=3.4-$ 3.6 GPa, and $\left.T=720-760^{\circ} \mathrm{C}\right)$. The persistence of monomineralic quartz in the coesite stability field $(P>2.7 \mathrm{GPa})$ suggests a minimum pressure difference of $1 \mathrm{GPa}$ between garnet core and rim during prograde metamorphism.

At a larger scale, the evidence for pressure variations becomes more indirect compared to the inclusion-host pair and the experimental capsule where pressure variations can be verified by 'in situ' observations and measurements. It is, therefore, difficult to distinguish pressure indicators that developed at the same time in different places from pressure indicators that formed during different stages of the $P-T$ evolution of a rock. For this reason, the interpretation of pressure variations depends on the mechanical model assumed (lithostatic, dynamic, etc). There are several field studies that report the existence of pressure variations developed and preserved over geological timescales. More specifically, metamorphic rocks recording different pressures without being tectonically juxtaposed point towards development of pressure variations during their formation. Aranovich (1992) documented pressure variations significantly exceeding zone thickness (even when adjusted for $10-20 \%$ tectonic thinning) for a number of Phanerozoic metamorphic kyanite-sillimanite complexes. Within the Adula nappe of the Swiss Alps, peak-pressure estimates record a pressure gradient that exceeds the lithostatic pressure gradient (cf. Nagel, 2008 and references therein). Similarly, for the Yenisey Ridge, Siberia, Likhanov and Reverdatto (2009) calculated employing conventional thermobarometry, pressure variations in rocks that show no evidence of tectonic juxtaposition. Moreover, the recorded pressures decrease with the distance from a thrust (Likhanov and Reverdatto, 2009). Hacker et al. (2010) presented a three-dimensional rendering of the calculated pressures for UHP eclogites from the Western Gneiss Region, Norway. The rendering revealed that the highest pressures preserved occur as anomalies in a generally smooth pressure-gradient pattern. Interestingly, Vrijmoed et al. (2006) and Vrijmoed (2009) reported pressure variations, at the outcrop scale, of the order of $3 \mathrm{GPa}$ in peridotites from that region. It has also been suggested that different mineral assemblages occurring in the hinges and limbs of folds (e.g. Mörk, 1985; see also Smith, 1988) represent 'in situ' developed pressure variations.

At the lithosphere scale, the distribution of earthquakes and their comparison with rock-deformation experiments suggest a maximum of rock strength close to the brittle-ductile transition (Chen and Molnar, 1983). Typical values of differential stresses that the rocks can support are between 0.5 and 1.5 GPa (Brace and Kohlstedt, 1980). These values demonstrate nonlithostatic pressure distributions compared to the lithostatic model that assumes no differential stresses. Gigapascal-level differential stresses seem to be in disagreement with typical earthquake stress drops (Kanamori and Brodsky, 2004). However, earthquake stress drops can only serve as a lower bound of the magnitude of the total stress. Less frequent earthquakes with stress drops up to 0.5-1.0 GPa (Prieto et al., 2012) document that such levels of stress are attainable within the lithosphere implying that the mechanisms 
(a)

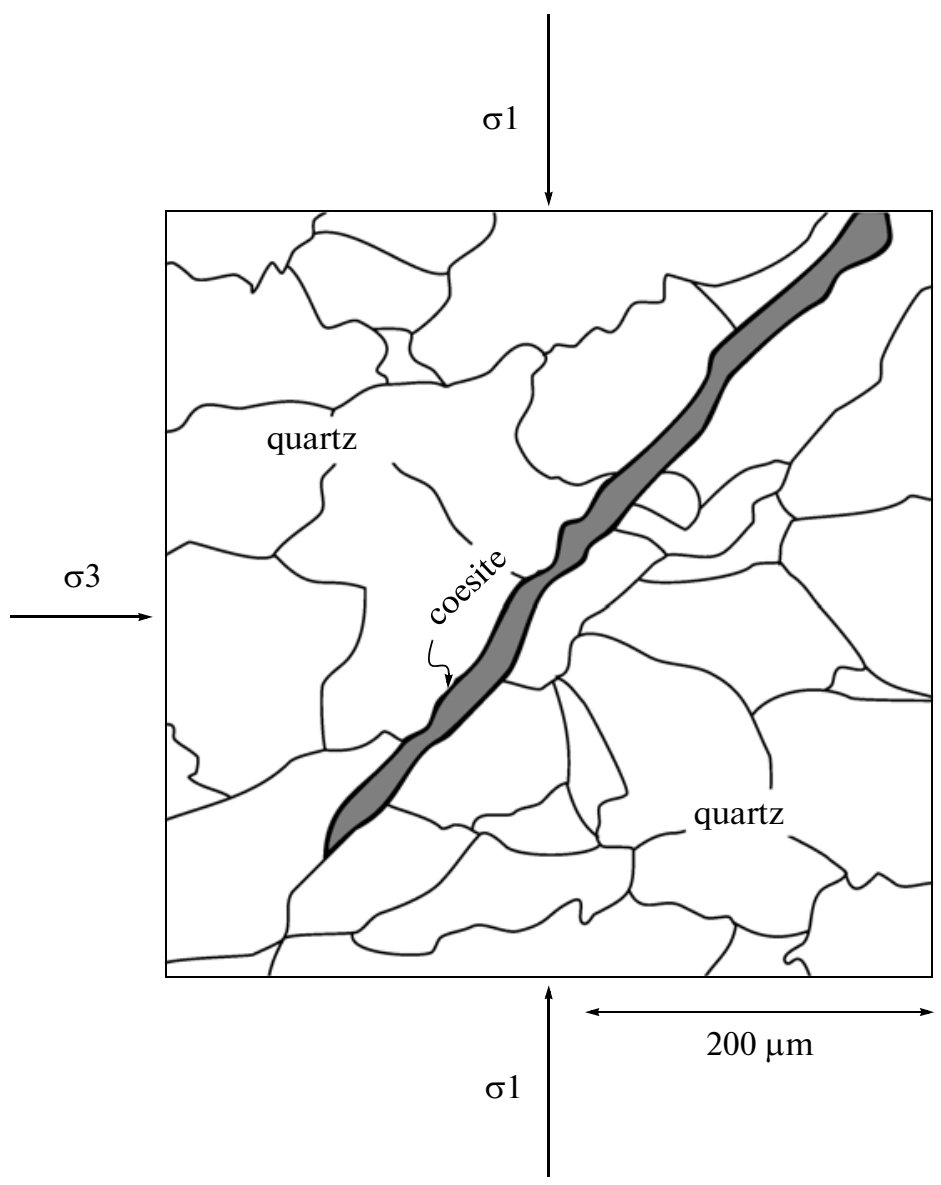

(b)

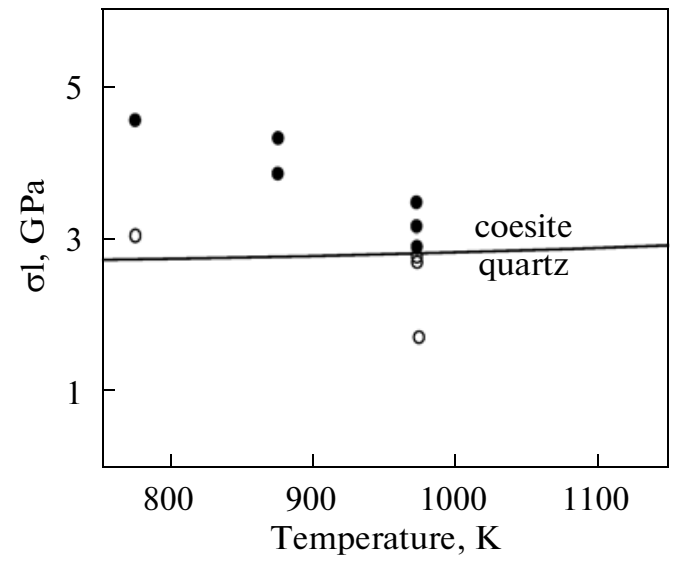

(c)

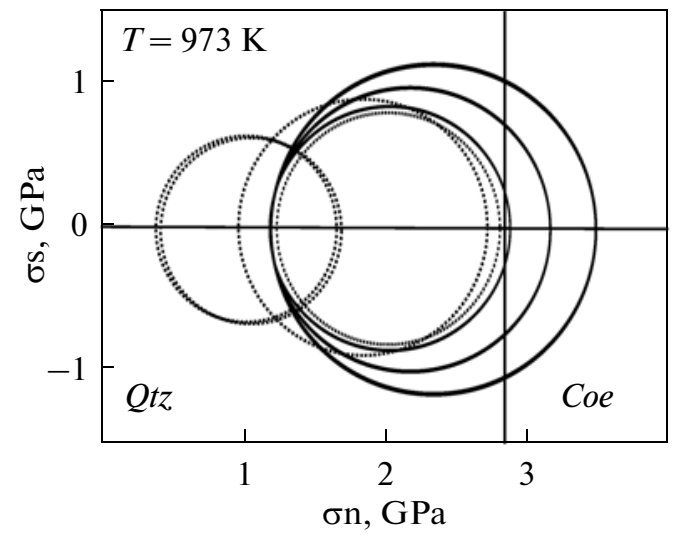

Fig. 3. (a) Sketch of optical micrograph of quartzite deformed in the semibrittle faulting regime showing the development of coesite adjacent to a fault zone (sample CQ25 from the experimental work of Hirth and Tullis, (1994); $T=873 \mathrm{~K}$; confining pressure $\sigma 2=\sigma 3 \approx 1.25 \mathrm{GPa}$ ). The shortening direction is vertical. Apart from the coesite band shown, coesite was also observed along grain boundaries perpendicular to $\sigma 1$. (b) Principal stress $(\sigma 1)$ versus temperature plot for the quartzite deformation experiments of Hirth and Tullis (1994). Filled circles indicate the presence of coesite. The quartz-coesite phase boundary was calculated using the thermodynamic database of Holland and Powell, (1998). (c) Construction of Mohr's circles for the experiments of Hirth and Tullis, (1994) at $973 \mathrm{~K}$. The quartz-coesite boundary $(\mathrm{Qtz}-\mathrm{Coe})$ is indicated by the vertical line. The state of stress for coesitebearing samples is indicated by the solid circles.

responsible for them do exist and that the rocks are strong enough to sustain them.

\section{MECHANICAL STUDIES SUPPORTING THE DEVELOPMENT OF PRESSURE VARIATIONS}

The potential magnitudes of the pressure variations discussed in the previous section range between ca. 0.1 to $12 \mathrm{GPa}$. These pressure variations are best viewed as differences in thermodynamic pressures predicted by mineral equilibria. Theoretical studies have quantified pressure variations for several geological scenarios (see review in Mancktelow, 2008). Li et al. (2010) suggested that the pressure developed in a subduction channel is around 1.1-1.2 times the lithostatic value. Larger values were also observed in the lithospheric mantle region in the above numerical experiments and, in some cases, in the crust (see also Gerya et al., 2008). Mancktelow (1995) suggested that the magnitude of pressure in the subduction channel may reach up to $2 \mathrm{GPa}$ at a depth of ca. $40 \mathrm{~km}$. Using simple mechanical arguments, Petrini and Podladchikov (2000) demonstrated that the pressure gradient in compressive regions of thickened crust may be up to two times the lithostatic gradient, i.e.

$$
P=2 \rho g h \text {. }
$$

They derived this estimate by employing a brittle rheology and making several simplifying assumptions about the principal stress components. When they adopted a visco-elasto-plastic rheology, their finiteelement calculations revealed a Christmas tree-like pressure-depth profile, with pressure values varying between those predicted by equations (1) and (2). Nevertheless, Petrini and Podladchikov (2000) con- 

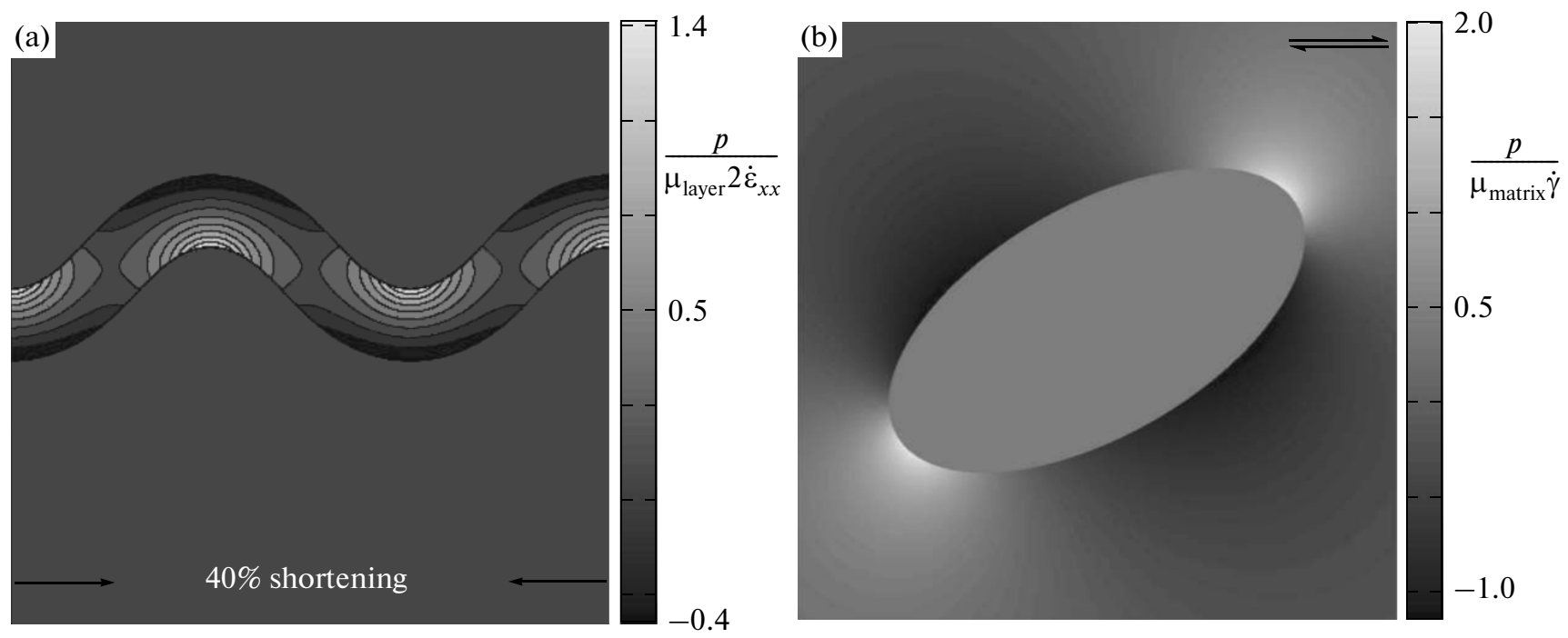

Fig. 4. Calculated pressure values (normalized to the viscosity times the far-field strain rate) for the cases of: (a) folding of a viscous incompressible layer. The layer is 50 times more viscous than the matrix-see also Schmalholz and Podladchikov, (1999) and Mancktelow, (2008), and (b) shearing of an elliptical inclusion. The inclusion is 10 times less viscous than the rest of the matrix. Note the elevated pressure also inside the inclusion (after Schmid and Podladchikov, 2003).

sidered only the early stages of lithospheric thickening that are dominated by pure shear. This is somewhat difficult to recognize in natural settings due to latestage metamorphism and simple shear deformation. More recently, Schmalholz and Podladchikov (2013) demonstrated the persistence of such early-stage overpressures up to the latest stages of lithosphere failure via formation of crustal-scale shear zones. Their final strain patterns resemble essential features of natural nappes, thereby confirming the relevance of Eq. (2) to the entire cycle of mountain building starting from pure-shear dominated thickening up to simple-shear dominated nappe stacking (Burg and Podladchikov, 2000; Burg and Schmalholz, 2008). Moreover, Schmalholz and Podladchikov (2013) showed that force balance across the shear zone requires a pressure anomaly up to two times the lithostatic value even within the weak shear zone. Recent quantitative studies (Regenauer-Lieb et al., 2012) suggested pressures even $>3$ times the value of the lithostatic gradient attained by UHP rocks in the Alps. In addition, Mancktelow (2008) explained how geometric factors could lead to large deviations from the background pressure value if both overpressure and underpressure are considered (Fig. 4). At smaller length scales, Schmid and Podladchikov (2003) obtained analytical solutions for the pressure distribution around geological objects demonstrating the spatial distribution of pressure.

Experimental studies also suggest the development of heterogeneous pressure as revealed by the coexistence of $\mathrm{SiO}_{2}$ polymorphs in quartzite deformation experiments (Hirth and Tullis, 1994). Ji and Wang (2011) used the concept of interfacial friction-induced pressure to explain the large pressure developed along grain boundaries in the intergranular region. In the present work, we use the Mohr circle as a geometric representation of the 2-D transformation of stresses to prove this point (Fig. 5). Hirth and Tullis (1994) stated that "coesite is present along fault zones... and along grain boundaries oriented perpendicular to $\sigma 1$ " (see also Fig. 3). The state of stress between the deforming quartz and the newly-formed coesite can be described by two Mohr circles for stress. Stress equilibrium across the grain boundaries would require that the two Mohr circles intersect (cf. Strömgärd, 1973; Treagus, 1973; Mancktelow, 1993). Growth of the newly formed phase is not dominated by the differential stress but by the thermodynamic pressure. Growing an initially unstressed new phase (minimum free energy), and considering stress equilibrium at the boundaries, would require that its pressure should be close to $\sigma 1$ or to $\sigma 3$. In the case of the experiments of Hirth and Tullis (1994), coesite formed because the local pressure was close to $\sigma 1$ (Fig. 5). In other words, only $\sigma 1$ was in the stability field of coesite. The experimental data of Hirth and Tullis (1994) leave no doubt that local deviations from confining pressure were responsible for the formation and preservation of coesite (see also Figs. 3b, 3c).

The volumetric strain of minerals included in other phases with different mechanical and thermodynamic properties has been used to explain the pressures preserved in mineral inclusions (e.g. Rosenfeld and Chase, 1961). This mechanism is known as the "pressure vessel" effect and relies upon the expansion of mineral inclusions during decompression of the host. Differential expansion between inclusion and host is enough to generate GPa-level pressure variations that are responsible for the preservation of high-pressure 
(a)

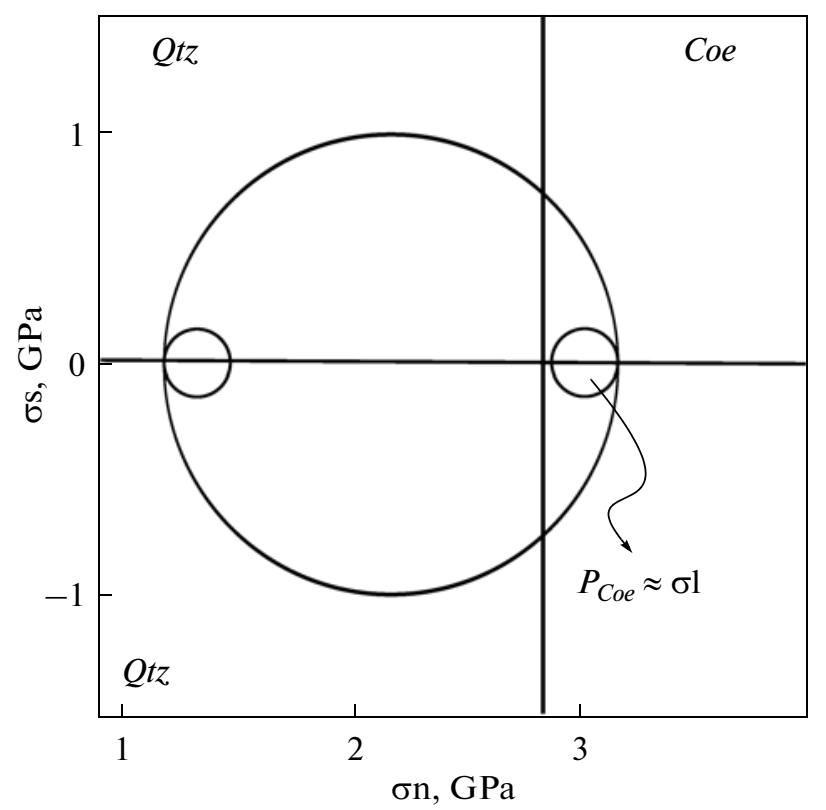

(b)

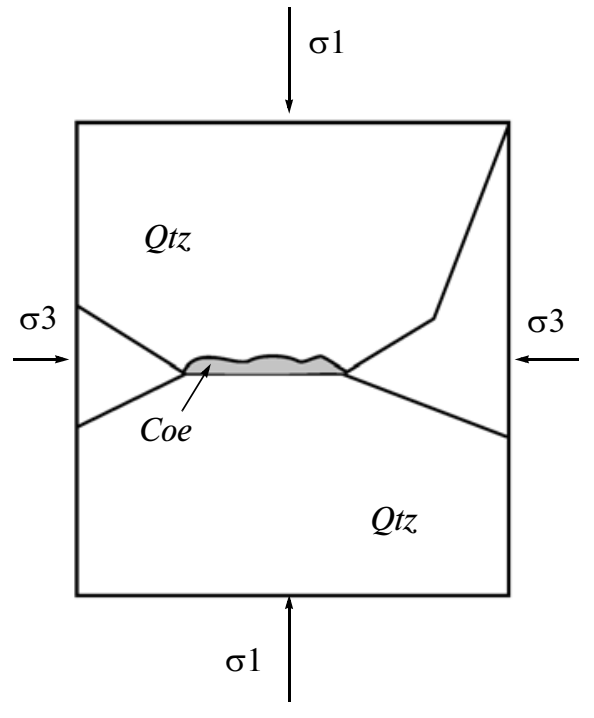

Fig. 5. Mechanical model for the development of coesite in the intergranular region of a deforming quartzite (based on the experiments of Hirth and Tullis, 1994): (a) Mohr's space, and (b) physical space. Temperature is assumed 973 K. Stress balance requires a discontinuity in pressure between the growing coesite and the matrix. Growing of a new phase under low differential stress would require that the new phase will be represented by a Mohr's circle with smaller radius. Considering stress equilibrium at the quartzcoesite interface would constrain the Mohr's circle of stress for coesite to intersect the one for quartz which is under stress. Therefore, the pressure of coesite is close to the value of $\sigma 1$ of the matrix if the surface of the grain is facing $\sigma 1$.

polymorphs like coesite (e.g. Gillet et al., 1984; Smith, 1984). Vrijmoed et al. (2009) used this concept to explain large pressure variations associated with the excess volume needed for melting. In that model, the excess volume needed for melting would be the cause of a pressure rise in the melting region if volume is not claimed (see also Fig. 6). A noteworthy feature in this model is that the strength of the material constituting the vessel plays a secondary role in the development of the pressure variations because the effective strength of the vessel is also controlled by its thickness and its geometry (see also Jamieson, 1963; Mancktelow, 2008). Therefore, at near-melting conditions, melting can be inhibited if volume is not available. If there is no change in volume, melting may not even begin. Changes in the system volume would enhance melting and pressure will not drop unless all of the volume needed for melting is claimed. Consequently, the break-down of the vessel would cause an almost isothermal decompression while melt is being produced.

\section{DEVELOPMENT AND PRESERVATION OF HETEROGENEOUS PRESSURE: A DEBATE}

The development and preservation of pressure variations in rocks have undergone severe criticism in the geological literature (e.g., Brace et al., 1970; Green, 2005). Despite the high differential stresses measured in the laboratory by Brace et al. (1970), these authors rejected the possibility of overpressure in crustal rocks maintaining that the high fluid pressures and low strain rates pertaining to the geological environment make rocks incapable of supporting high stresses. Based on that argumentation the concept of overpressure was judged as "failed" by Green (2005).

An overview of the existing quantitative mechanical studies shows that there is a positive correlation between the strength of the rocks and the magnitude of pressure variations, i.e., overpressure is more frequently observed in eclogites and peridotites which appear to be stronger than wet quartzite (Yamamoto et al., 2008; Moghadam et al., 2010). Using quartz rheology to approximate the upper crust as a whole (e.g., Burov et al., 2001) cannot resolve the pressure variations observed at the outcrop scale. Indeed, field evidence suggests that most of the high-pressure information is preserved in eclogites and peridotites (cf. Godard, 2001; Rumble et al., 2003) and not in the surrounding quartzites or felsic gneisses. In other words, the assumption of a homogeneous rheology in a homogenous subduction channel is inconsistent with the geological and geophysical findings that suggest a heterogeneous crust with mafic and ultramafic inclusions and layers (Meissner and Kern, 2008). Contrary to the low overpressures in the subduction channel predicted by the aforementioned studies, high overpressures were predicted in the overriding plate at mid-crustal levels and in the lithospheric mantle 

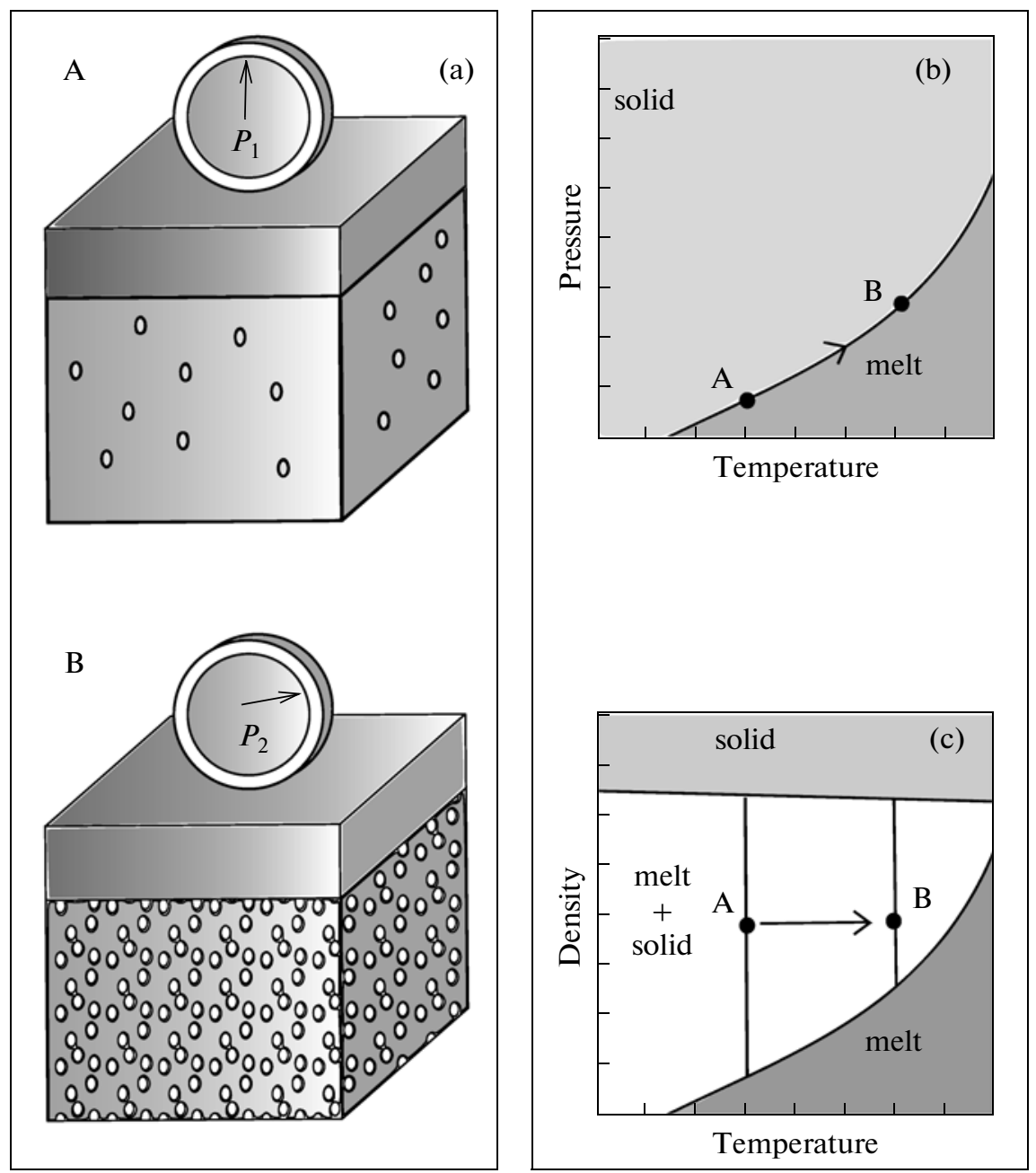

Fig. 6. (a) Conceptual model of a pressure vessel in the (b) $P-T$ and (c) $\rho-T$ space. When a rock reaches its solidus (e.g. case A), a change in volume (and density) is needed for melting to occur. If the change in rock volume does not occur instantly, the rock will follow a path of increasing pressure (case B) along the solidus (e.g. from A to B in b and c). If the pressure is relaxed and the volume is adjusted, the actual path of the rock will correspond to a pressure spike in the $P-T$ diagram. Note that if the system is allowed to decrease its density, melt production will be enhanced as revealed by the "lever rule" in c.

(Li et al., 2010, their Fig. 8; Gerya et al., 2008). This is consistent with the pressure gradient predicted by Petrini and Podladchikov (2000) for rocks in the brittleductile transition that display a pressure twice the lithostatic value and can explain even ultrahigh-pressure conditions for strong lithologies. The significant overpressure predicted by the simulations of $\mathrm{Li}$ et al. (2010) and Gerya et al. (2008) is restricted to strong rocks; weak rocks usually exhibit low overpressure values. Rocks that have returned to near-surface conditions from great depths within the weak subduction channel do not record significant overpressures (Li et al., 2010). The numerical results of Schmalholz and Podladchikov (2013) also show negligible overpressures in the mantle part of crustal-scale shear zones. Their results clearly demonstrate, however, that during continental collision significant overpressure can occur in weak crustal shear zones, i.e. overpressure significantly larger than the strength of the rock recording it. Most workers place UHP rocks in the deep mantle part of a weak subduction channel simply by translating pressure estimates from geothermobarometry directly into depth neglecting entirely the effects of overpressure (e.g. Jolivet et al., 2003). Schmalholz and Podladchikov (2013) have nonetheless shown that the concept of negligible overpressure may not be universally applicable to all weak shear zones. According to these authors, the satisfaction of the horizontal force balance during continental collision requires the development of significant overpressure in weak crustal rocks hence the record of high pressure by these lithologies. Interestingly, Schreyer (1995) argued that the pyrope-coesite paragenesis in the Dora Maira UHP rocks formed at the expense of a weak, phyllosilicate-rich matrix, i.e. a relatively weak lithology. 


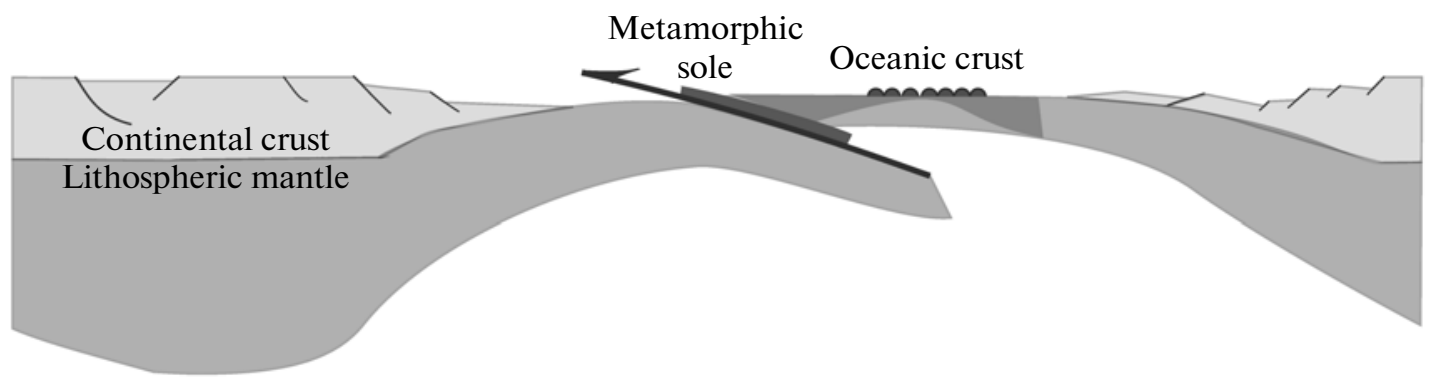

Fig. 7. Cartoon showing ophiolite obduction just after initiation of intraoceanic subduction. The cartoon has been drawn assuming that the continental crust is ca $35 \mathrm{~km}$ thick. Typical thickness of oceanic crust does not exceed $7 \mathrm{~km}$.

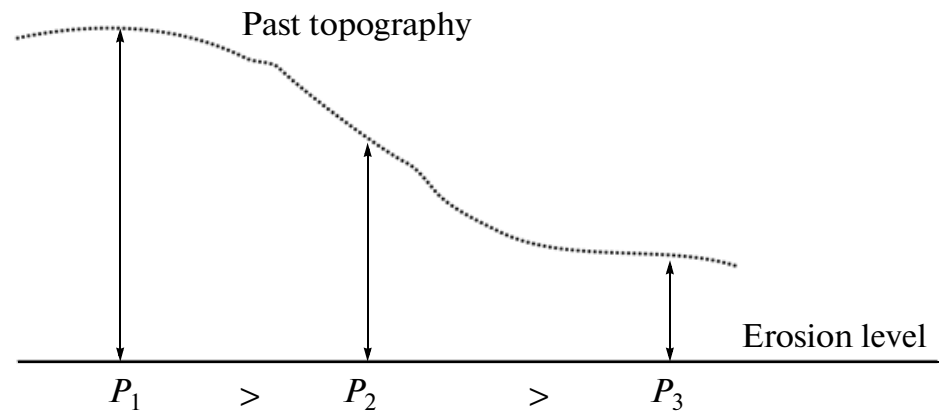

Fig. 8. Model using the lithostatic load as an explanation for the development of a horizontal pressure gradient in rocks without tectonic juxtaposition (after Likhanov and Reverdatto, 2009). See text for details.

The above mechanical arguments do not concern pressure vessel scenarios and inclusion-host relationships (see also Smith, 1988; 1995). The fact that the pressure indicators are usually preserved as inclusions in minerals or are limited to small volumes in the rocks suggests that they may be products of reactioninduced overpressures as in the case of Vrijmoed et al. (2009). In such a model, rheology cannot be the sole argument against the development of overpressure since the vessel thickness is playing a crucial role maintaining the pressure variations, very much like in the experimental laboratory where gas or salt are used to confine the rocks up to $\mathrm{GPa}$-level pressures (cf. Mancktelow, 2008). Therefore, more quantitative studies are needed to account for the additional effects of reaction-induced dilational deformation.

\section{THE IMPORTANCE OF PRESSURE VARIATIONS IN GEOLOGICAL RECONSTRUCTIONS}

As briefly reviewed above it is possible, due to various mechanical reasons, to achieve pressures up to two times the lithostatic value. Therefore, the use of Eq. (1) is not always warranted. Indeed, the geological literature is riddled with examples where depth estimates from pressure calculations and geological considerations do not agree with each other. Pressure estimates for metamorphic soles occurring beneath obducted ophiolites (e.g. Albania, Greece, Oman;
Fig. 7) cannot be explained by the observed thickness of the overlying complexes (e.g. Searle and Cox, 1999; Garfunkel, 2006; Myhill, 2011). Considerable thinning of the ophiolite after sole formation is invoked to explain the missing material (Wakabayashi and Dilek, 2003), but this thinning is absent or not documented (Garfunkel, 2006).

Another example of a pressure-to-depth geological problem is the interpretation of documented pressure gradients in metamorphic terranes (e.g. Likhanov and Reverdatto, 2009). Using the lithostatic formula Eq. (1) to explain horizontal pressure gradients such as those depicted in Fig. 8 implies that the rocks behave like fluids (i.e. they are weak) and that they are in static equilibrium. As shown in Fig. 8, different pressures caused by different lithostatic loads would create a pressure gradient in the horizontal direction, but for the pressure gradient to be maintained over geologic time the rocks would have to be strong so that they would not flow laterally in order to equilibrate the pressure gradient. Maintaining the horizontal pressure gradient contradicts the initial assumption (i.e. that rocks are so weak that the hydrostatic formula applies).

Discussion of ultrahigh-pressure (UHP) metamorphism of crustal rocks is pivotal at this point. Crustal rocks exhibit significantly lower densities compared to mantle rocks, thus making continental subduction a difficult task. Even if continental rocks do subduct, 
their exhumation from great depths is recognized as problematic (e.g. Condie, 2011). Exhumation from depths exceeding the equivalent of $8.5 \mathrm{GPa}$ in pressure is impossible because at such pressures continental material becomes much denser than the surrounding mantle peridotite (Irifune et al., 1994). Preserved pressure variations that cannot be explained by the thickness of the overlying rocks (e.g. Adula nappe, Swiss Alps; see Nagel, 2008 for a review) and exhumation rates that do not fit the geological observations (e.g. Ford et al., 2006) are among the most common problems that arise when pressure translates into depth of metamorphism via Eq. (1). Unless translithospheric diapirism is invoked (e.g. Ellis et al., 2011), common exhumation scenarios for high-pressure rocks involve rapid movements within the subduction channel. Worth mentioning here is that in subduction channels the contrast in viscosities of the involved lithologies would lead to deviations from lithostatic pressure (see Mancktelow, 2008 for analytical and numerical verification); put another way, one of the major mechanisms to bring rocks back to the surface from great depths would require that the pressure is not literally lithostatic (Mancktelow, 1995).

The discovery of diamond, coesite after stishovite, silicon carbide, $\mathrm{TiO}_{2}$-II and high-pressure nitrides in podiform chromitites hosted in harzburgite from the Luobusa ophiolite (Bai et al., 2000; Yang et al., 2007; Dobrzhinetskaya et al., 2009) raised additional questions regarding the simple pressure-to-depth conversion. The chromitites were formed in a suprasubduction zone environment from boninitic melts reacting with the host peridotites at depths less than $35 \mathrm{~km}$ (Zhou et al., 1996; Robinson et al., 2004). Transportation of the UHP minerals from the lower mantle by a plume with subsequent incorporation in the ophiolite during seafloor spreading as well as a meteorite impact were proposed by the previous authors. At any rate, in the high-temperature environment of chromitite formation $\left(\sim 1300^{\circ} \mathrm{C}\right)$, sluggish kinetics cannot be the reason for preservation of diamond and coesite; preservation of these high-pressure polymorphs indicates large pressure variations when the rocks were still at high temperature.

\section{CONCLUDING REMARKS}

Stresses that develop during deformation of geologic materials can be responsible for the formation and preservation of GPa-level pressure variations. Considering that the typical value of the lithostatic pressure at the base of the continental crust is $\sim 1 \mathrm{GPa}$, GPa-level variations make the interpretation of depth from pressure problematic for crustal metamorphic rocks. Preserved residual pressures in inclusions can reach values of 1-2 and up to 3.5 GPa while the development of coherent exsolution lamellae in feldspars suggests the in situ development of pressure variations of the order of $1 \mathrm{GPa}$. Rock deformation experiments in polycrystalline-polymineralic (quartz and minor muscovite) quartzite suggest the in-situ development of pressure variations that were responsible for the formation of coesite, a polymorph that defines the official entry into UHP metamorphic conditions. These results are particularly important when considering lithosphere dynamics under general compression. In such a case, $\sigma 3$ would be the stress from the overburden but the mineral assemblage could form as a response to the pressure value that lies anywhere between the principal stresses ( $\sigma 1$ and $\sigma 3$ ). By using the maximum stresses from the experiments of Hirth and Tullis (1994) (Fig. 3c) it becomes apparent that coesite formed at pressure $>2 \sigma 3$. It can be further suggested that strong minerals like omphacite or garnet may enhance the crystallization of high-pressure polymorphs as a response to the high differential stress that they can sustain. This would lead to the formation and preservation of UHP mineral assemblages as a response to the local stress conditions rather than to complex $P-T-t$ paths.

From a geodynamic point of view, the greatest challenge in estimating depth from pressure is by far the exhumation mechanism of UHP metamorphic rocks. Rocks that demonstrably underwent UHP metamorphism, are commonly interpreted to have formed at depths of $100 \mathrm{~km}$ or more. Subductionrelated processes are usually invoked to explain the exhumation of UHP rocks from great depths (e.g. Boutelier and Chemenda, 2008). However, there are well known cases where subduction has been excluded as a mechanism to explain the exhumation of such rocks (Yang et al., 2007; Ellis et al., 2011; Little et al., 2011). Moreover, rapid decompression rates have been estimated by independent petrologic/geochronologic studies (Hermann et al., 2001; Stöckhert et al., 2009) and if Eq. (1) is used to estimate depth from the pressure calculation, high exhumation rates are concluded. These exhumation rates are supported only by mineralogical evidence and Eq. (1). Therefore, in such cases, the possibility of tectonic and/or reactioninduced overpressure has to be seriously taken into consideration as an important additional mechanism to explain the high pressures calculated without resorting to subduction to great depths. Tectonic and/or reaction-induced overpressure would be in agreement with the data supporting:

- short residence time at UHP conditions (e.g. Dobrzhinetskaya et al., 2006)

- rapid decompression rates (e.g. Hermann et al. 2001, Stöckhert et al., 2009)

- the physicochemical conditions of diamond formation from UHP rocks that indicate the presence of a melt or a supercritical fluid (e.g. Hwang et al., 2001; Korsakov et al., 2004; Stöckhert et al., 2001; Stöckhert et al., 2009)

- geological reconstructions that do not require large slabs being subducted, and rapid exhumation 
rates like those seen in the Alpine region (e.g. Ford et al., 2006; Regenauer-Lieb et al., 2012).

We conclude that tectonic and/or reactioninduced overpressure are quite plausible physical mechanisms for explaining geological observations where the lithostatic formula fails to do so. Mechanical models requiring deep subduction processes have to be reconsidered if no evidence other than high pressure estimates is present.

\section{ACKNOWLEDGMENTS}

Johannes Vrijmoed (UL), Lucie Tajcmanova, James Connolly and Jean-Pierre Burg (all of ETH-Z) are thanked for stimulating discussions. Stefan Schmalholz (UL) is thanked for helpful discussions and constructive comments on the manuscript. We also thank Neil Mancktelow and Filippo Schenker (both of ETH-Z) for fruitful discussions and for providing us Fig. 4a and Fig. 7 respectively. Constructive comments by Alex Pack (IGEM RAS) on the earlier draft of the manuscript helped to clarify presentation. E.M. acknowledges the Alexander. S. Onassis Public Benefit Foundation for financial support. D.K. acknowledges a University of Athens Kapodistrias fund (70/4/7622). Financial support by ESD RAS (Program 9) to LYA is also appreciated.

\section{REFERENCES}

Aranovich, L.Y., Mineral equilibria of multi-component solid solutions, Moscow: Nauka Press, 1991 [in Russian].

Bai, W., Robinson, P.T., Fang, Q., et al., The PGE and base-metal alloys in the podiform chromitites of the Luobusa ophiolite, Southern Tibet, Can. Mineral., 2000, vol. 38, pp. 585-598.

Boutelier, D.A. and Chemenda, A.I., Exhumation of UHP/LT rocks due to local reduction of the interplate pressure: thermo-mechanical physical modeling, Earth Planet. Sci. Lett., 2008, vol. 271, pp. 226-232.

Burg, J.-P. and Podladchikov, Y., From buckling to asymmetric folding of the continental lithosphere: numerical modeling and application to the Himalayan syntaxes, in Tectonics of the Nanga Parbat Syntaxis and the Western Himalaya, Khan, M.A., Treloar, P.J., Searle, M.P. and Jan, M. Eds., Geol. Soc. Lond. Spec. Publ., 2000, vol. 170, pp. 219-236.

Burg, J.-P. and Schmalholz, S.M., Viscous heating allows thrusting to overcome crustal-scale buckling: numerical investigation with application to the Himalayan syntaxes, Earth Planet. Sci. Lett., 2008, vol. 274, pp. 189-203.

Brace, W.F., Ernst, W.G., and Wittels Kallberg, R., An experimental study of tectonic overpressure in Fransiscan Rocks, Geol. Soc. Am. Bull., 1970, vol. 81, pp. 1325-1338.

Brace, W.F. and Kohlstedt, D.L., Limits on lithospheric stress imposed by laboratory experiments, J. Geophys. Res., 1980, vol. 85, no. B11, pp. 6248-6252.

Burov, E., Jolivet, L., Le Pourhiet, L., and Poliakov, A., A thermomechanical model of exhumation of high pressure (HP) and ultra-high pressure (UHP) metamorphic rocks in Alpine-type collision belts, Tectonophysics, 2001, vol. 342, pp. 113-136.
Chen, W.P. and Molnar, P., Focal depths of intracontinental and intraplate earthquakes and their implications for the thermal and mechanical properties of the lithosphere, J. Geophys. Res., 1983, vol. 88, no. B5, pp. 4183-4214.

Chopin, C. and Sobolev, N.V., Principal mineralogical indicators of UHP in crustal rocks, in Ultrahigh pressure metamorphism, Coleman, R.G. and Wang, X., Eds., Cambridge: University Press, 1995, pp. 96-131.

Chopin, C., Ultrahigh-pressure metamorphism: tracing continental crust into the mantle, Earth Planet. Sci. Lett., 2003, vol. 212, 1-14.

Condie, K.C., Earth as an Evolving Planetary System (Elsevier Academic Press, 2011).

Dobrzhinetskaya, L.F., Liu, Z., Cartigny, P., et al., Synchrotron infrared and Raman spectroscopy of microdiamonds from Erzgebirge, Germany, Earth Planet. Sci. Lett., 2006, vol. 248, pp. 340-349.

Dobrzhinetskaya, L.F., Wirth, R., Yang, J., et al., Highpressure highly reduced nitrides and oxides from chromitite of a Tibetan ophiolite, Proc. Nat. Ac. Sci., 2009, vol. 106, no. 46 , pp. $19233-19238$.

Ellis, S.M., Little, T.A., Wallace, L.M., et al., Feedback between rifting and diapirism can exhume ultrahigh-pressure rocks, Earth Planet. Sci. Lett., 2011, vol. 311, 427-438. Enami, M., Nishiyama, T., and Mouri, T., Laser Raman microspectrometry of metamorphic quartz: A simple method for comparison of metamorphic pressures, Am. Mineral., 2007, vol. 92, pp. 1303-1315.

Ernst, W.G., Petrogenesis of Glaucophane Schists, J. Petrol., 1963, vol. 4, pp. 1-30.

Eskola, P., On the role of pressure in rock crystallization, Bull. Comm. Geol. Finl., 1929, vol. 85, pp. 77-88.

Ford, M., Duchene, S., Gasquet, D., and Vanderhaeghe, O., Two-phase orogenic convergence in the external and internal SW Alps, J. Geol. Soc., 2006, vol. 163, pp. 815-826.

Garfunkel, Z., Neotethyan ophiolites: formation and obduction within the life cycle of the host basins, in Tectonic Development of the Eastern Mediterranean Region, Robertson, A.H.F. and Mountrakis, D. Eds., Geol. Soc. Lond. Spec. Publ., 2006, vol. 260, pp. 301-326.

Gerya, T.V., Perchuk, L.L., and Burg, J.-P., Transient hot channels: Penetrating and regurgitating ultrahigh-pressure, high-temperature crust-mantle associations in collision belts, Lithos, 2008, vol. 103, pp. 236-256.

Gillet, Ph., Ingrin, J., and Chopin, C., Coesite in subducted continental crust: $P-T$ history deduced from an elastic model, Earth Planet. Sci. Lett., 1984, vol. 70, pp. 426-436.

Godard, G., Eclogites and their geodynamic interpretation: a history, J. Geodyn., 2001, vol. 32, pp. 165-203.

Godard, G., Frezzotti, M.L., Palmeri, R., and Smith, D., Origin of high-pressure disordered metastable phases (lonsdaleite and incipiently amorphised quartz) in metamorphic rocks: geodynamic shock or crystal-scale overpressure?, in UHPM: 25 Years after the Discovery of Coesite and Diamond, Dobrzhinetskaya, L., Cuthbert, S., Faryad, W. and Wallis, S., Eds., Elsevier, 2011, pp. 125-148.

Green, H.W., Psychology of a changing paradigm: $40+$ years of high-pressure metamorphism, Int. Geol. Rev., 2005, vol. 47, pp. 439-456.

Hacker, B.R., Andersen, T.B., Johnston, S., et al., Hightemperature deformation during continental-margin subduction and exhumation: the ultrahigh-pressure Western 
Gneiss Region of Norway, Tectonophysics, 2010, vol. 480, pp. 149-171.

Hermann, J., Rubatto, D., Korsakov, A., and Shatsky, V., Multiple zircon growth during fast exhumation of diamondiferous, depply subducted continental crust (Kokchetav Massif, Kazakhstan), Contrib. Mineral. Petrol., 2001, vol. 141, pp. 66-82.

Hirth, G. and Tullis, J., The brittle-plastic transition in experimentally deformed quartz aggregates, J. Geophys. Res., 1994, vol. 99, no. B6, pp. 11731-11747.

Holland, T.J.B. and Powell, R., An internally consistent thermodynamic data set for phases of petrological interest, J. Metamorph. Geol., 1998, vol. 16, pp. 309-343.

Howell, D., Wood, I.G., Dobson, D.P., et al., Quantifying strain birefringence halos around inclusions in diamond, Contrib. Mineral. Petrol., 2010, vol. 160, pp. 705-717.

Hwang, S.-L., Shen, P., Chu, H., et al., Genesis of microdiamonds from melt and associated multiphase inclusions in garnet of ultrahigh-pressure gneiss from Erzgebirge, Germany, Earth Planet. Sci. Lett., 2001, vol. 188, pp. 9-15.

Irifune, T., Ringwood, A.E., and Hibberson, W.O., Subduction of continental crust and terrigenous and pelagic sediments: an experimental study, Earth Planet. Sci. Lett., 1994, vol. 126, pp. 351-368.

Jamieson, J.C., Possible occurrence of exceedingly high pressures in geological processes, Geol. Soc. Am. Bull., 1963, vol. 74, pp. 1067-1070.

$\mathrm{Ji}, \mathrm{S}$. and Wang, Q., Interfacial friction induced pressure and implications for the formation and preservation of intergranular coesite in metamorphic rocks, J. Struct. Geol., 2011, vol. 33, pp. 107-113.

Jolivet, L., Faccenna, C., Goffé, B., Burov, E., and Agard, P., Subduction tectonics and exhumation of high-pressure metamorphic rocks in the Mediterranean orogens, Am. J. Sci., 2003, vol. 303, 353-409.

Kanamori, H. and Brodsky, E.E., The physics of earthquakes, Rep. Prog. Phys., 2004, vol. 67, pp. 1429-1496.

Korsakov, A.V., Theunissen, K., and Smirnova, L.V., Intergranular diamonds derived from partial melting of crustal rocks at ultrahigh-pressure metamorphic conditions, Terra Nova., 2004, vol. 16, pp. 146-151.

Korzhinskii, D.S., Faktory mineral'nyh ravnovesii i mineralogicheskie facii glubinnosti (Factors of Mineral Equilibria and Mineralogical Facies of Depth), Moscow; IGN, 1940.

Korzhinskii, D.S., Physico-Chemical Basis of the Analysis of the Paragenesis of Minerals, New York: Consultants Bureau, 1959.

Li, Z.H., Gerya, T.V., and Burg, J.-P., Influence of tectonic overpressure on $P-T$ paths of HP-UHP rocks in continental collision zones: thermomechanical modeling, J. Metamorph. Geol., 2010, vol. 28, pp. 227-247.

Likhanov, I.I. and Reverdatto, V.V., Neoproterozoic collisional metamorphism in overthrust terranes of the TransAngarian Yenisey Ridge, Siberia, Int. Geol. Rev., 2009, vol. 53, no. 7, pp. 802-845.

Little, T.A., Hacker, B.R., Gordon, S.M., et al., Diapiric exhumation of Earth's youngest (UHP) eclogites in the gneiss domes of the D'Entrecasteaux Islands, Papua New Guinea, Tectonophysics, 2011, vol. 510, pp. 39-68.

Mancktelow, N.S., Tectonic overpressure in competent mafic layers and the development of isolated eclogites, J. Metamorph. Geol., 1993, vol. 11, pp. 801-812.

Mancktelow, N.S., Nonlithostatic pressure during sediment subduction and the development and exhumation of high pressure metamorphic rocks, J. Geophys. Res., 1995, vol. 100 , no. B1, pp. 571-583.

Mancktelow, N.S., Tectonic pressure: theoretical concepts and modelled examples, Lithos, 2008, vol. 103, 149-177.

Meissner, R. and Kern, H., Earthquakes and strength in the laminated lower crust - Can they be explained by the "corset model"?, Tectonophysics, 2008, vol. 448, pp. 49-59.

Moghadam, R.H., Trepmann, C.A., Stckhert, B., and Renner, J., Rheology of synthetic omphacite aggregates at high pressure and high temperature, J. Petrol., 2010, vol. 51, pp. 921-945.

Mörk, M.B.E., A gabbro to eclogite transition on Flemsy, Sunnmre, Western Norway, Chem. Geol., 1985, vol. 50, pp. 283-310.

Myhill, R., Constraints on the evolution of the Mesohellenic Ophiolite from subophiolitic metamorphic rocks, Geol. Soc. Am. Spec. Pap., 2011, vol. 480, pp. 75-94.

Nagel, T., Tertiary subduction, collision and exhumation recorded in the Adula nappe, Central Alps, in Tectonic aspects of the Alpine-Dinaride-Carpathian System, Siegesmund, S., Fügenschuh, B. and Froitzheim, N., Eds., Geol. Soc. Lond. Spec. Publ., 2008, vol. 298, pp. 365-392.

Nasdala, L., Brenker, F.E., Glinnemann, J., et al., Spectroscopic 2D-tomography: residual pressure and strain around mineral inclusions in diamonds, Eur. J. Mineral., 2003, vol. 15, pp. 931-935.

Palmeri, R., Ghiribelli, B., Ranalli, G., et al., Ultrahighpressure metamorphism and exhumation of garnet-bearing ultramafic rocks from the Lanterman Range (northern Victoria Land, Antarctica), J. Metamorph. Geol., 2007, vol. 25, pp. 225-243.

Palmeri, L., Frezzotti, M.L., Godard, G., and Davies, R.J., Pressure-induced incipient amorphization of a-quartz and transition to coesite in an eclogite from Antarctica: a first record and some consequences, J. Metamorph. Geol., 2009, vol. 27, pp. 685-705.

Parkinson, C.D. and Katayama, I., Present-day ultrahighpressure conditions of coesite inclusions in zircon and garnet: Evidence from laser Raman microspectroscopy, Geology, 1999, vol. 27, no. 11, pp. 979-982.

Parkinson, C.D., Coesite inclusions and prograde compositional zonation of garnet in whiteschist of the HP-UHPM Kokchetav Massif, Kazakhstan: a record of progressive UHP metamorphism, Lithos, 2000, vol. 52, pp. 215-233.

Perchuk, L.L., Pyroxene-garnet equilibrium and the depth facies of eclogites, Int. Geol. Rev., 1968, vol. 10, no. 3, pp. 280-318.

Perchuk, L.L., Equilibria of Rock-Forming Minerals, Moscow: Nauka Press, 1970.

Petrini, K. and Podladchikov, Y., Lithospheric pressuredepth relationship in compressive regions of thickened crust, J. Metamorph. Geol., 2000, vol. 18, pp. 67-77.

Prieto, G.A., Beroza, G.C., Barrett, S.A., et al., Earthquake nests as natural laboratories for the study of intermediate-depth earthquake mechanics, Tectonophysics, 2012, vol. 570-571, pp. 42-56.

Regenauer-Lieb, K., Rosenbaum, G., Weinberg, R.F., and Manatschal, G., Overpressure during indentation and the origin of ultra-high-pressure rocks in the Alps, AGU Fall Meeting, San-Francisco, 2012, pp. T33G-2742.

Robin, P., Stress and strain in cryptoperthite lamellae and the coherent solvus of the alkali feldspar, Am. Mineral., 1974, vol. 59, pp. 1299-1318. 
Robinson, P.T., Bai, W.-J., Malpas, J., et al., Ultra-high pressure minerals in the Luobusa Ophiolite, Tibet, and their tectonic implications, in Aspects of the Tectonic Evolution of China, Malpas, J., Fletcher, C.J.N., Ali, J.R. and Aitchison, J.C., Eds., Geol. Soc. Lond. Spec. Publ., 2004, vol. 226, pp. 247-271.

Roedder, E. and Kopp, O.C., A check on validity of the pressure correction in inclusion geothermometry, using hydrothermally grown quartz, Fortschr. Miner., 1975, vol. 52, pp. 431-446.

Rosenfeld, J.L. and Chase, A.B., Pressure and temperature of crystallization from elastic effects around solid inclusions in minerals? Am. J. Sci., 1961, vol. 259, pp. 519-541.

Rumble, D., Liou, G.J., and Jahn, B.M., Continental crust subduction and ultrahigh-pressure metamorphism, in Treatise on Geochemistry, Elsevier, 2003, vol. 3, pp. 293319.

Schmalholz, S.M. and Podladchikov, Y., Buckling versus folding. Importance of viscoelasticity, Geophys. Res. Lett., 1999, vol. 26, no. 17, pp. 2641-2644.

Schmalholz, S.M. and Podladchikov, Y.Y., Tectonic overpressure in weak crustal-scale shear zones and implications for the exhumation of high-pressure rocks, Geophys. Res. Lett., 2013,, DOI: 10.1002/grl.50417.

Schmid, D.W. and Podladchikov, Y.Y., Analytical solutions for the deformable elliptical inclusions in general shear, Geophys. J. Int., 2003, vol. 155, pp. 269-288.

Schmidt, C. and Ziemann, M.A., In-situ Raman spectroscopy of quartz: A pressure sensor for hydrothermal diamond-anvil cell experiments at elevated temperatures, Am. Mineral., 2000, vol. 85, no. 11-12, pp. 1725-1734.

Schreyer, W., Ultradeep metamorphic rocks: The retrospective viewpoint, J. Geophys. Res., 1995, vol. 100, pp. 8353-8366.

Searle, M. and Cox, J., Tectonic setting, origin and obduction of the Oman ophiolite, Geol. Soc. Am. Bull., 1999, vol. 111, pp. 104-122.

Smith, D.C., Coesite in clinopyroxene in the Caledonides and its implications for geodynamics, Nature, 1984, vol. 310, pp. 641-644.

Smith, D.C., A review of the peculiar mineralogy of the "Norwegian coesite-eclogite province", with crystal-chemical, petrological, geochemical and geodynamical notes and an extensive bibliography, in Eclogites and Eclogite-Facies Rocks, Smith, D.C., Ed., Elsevier, 1988, pp. 1-206.

Smith, D.C., Microcoesites and microdiamonds in Norway: an overview. in Ultrahigh Pressure Metamorphism, Coleman, R.G. and Wang X., Eds., Cambridge: University Press, 1995, pp. 299-355.

Sobolev, N.V., Fursenko, S.V., Goryainov, S.V., et al., Fossilized high pressure from the Earth's deep interior: the coesite-in-diamond barometer, Proc. Nat. Ac. Sci., 2000, vol. 97, no. 22, pp. 11875-11879.

Sobolev, N.V. and Shatsky, V.S., Diamond inclusions in garnets from metamorphic rocks: a new environment for diamond formation, Nature, 1990, vol. 343, pp. 742-746.

Stöckhert, B., Duyster, J., Trepmann, C., and Massonne, H.J., Microdiamond daughter crystals precipitated from super- critical $\mathrm{C}-\mathrm{O}-\mathrm{H}$ fluids included in garnet, Erzgebirge, Germany, Geology, 2001, vol. 29, pp. 391-394.

Stöckhert, B., Trepmann, C., and Massonne, H.J., Decrepitated UHP fluid inclusions: about diverse phase assemblages and extreme decompression rates (Erzgebirge, Germany), J. Metamorph. Geol., 2009, vol. 27, pp. 673684.

Strömgård, K.E., Stress distribution during formation of boudinage and pressure shadows, Tectonophysics, 1973, vol. 16, pp. 215-248.

Tajčmanová L., Podladchikov, Y., Powell, R., et al., Grain Scale Pressure Variations and Chemical Equilibrium in High Grade Metamorphic Rocks, (under review), 2013.

Treagus, S.H., Buckling stability of a viscous single-layer system, oblique to the principal compression, Tectonophysics, 1973, vol. 19, pp. 271-289.

Van der Molen, I. and Van Roermund, H.L.M., The pressure path of solid inclusions in minerals: the retention of coesite inclusions during uplift, Lithos, 1986, vol. 19, pp. 317-324.

Vrijmoed, J.C., Van Roermund, H.L.M., and Davies, G.R., Evidence of diamond-grade ultra-high pressure metamorphism and fluid interaction in the Svartberget $\mathrm{Fe}-\mathrm{Ti}$ garnet peridotite-websterite body, Western Gneiss Region, Norway, Mineral. Petrol., 2006, vol. 88, pp. 381-405.

Vrijmoed, J.C., Physical and Chemical Interaction in the Interior of the Caledonian Mountains of Norway, Oslo: Univ. Oslo, 2009.

Vrijmoed, J.C., Podladchikov, Y., Andersen, T.B., and Hartz, E., An alternative model for ultra-high pressure in the Svartberget $\mathrm{Fe}-\mathrm{Ti}$ garnet peridotite, Western Gneiss Region, Norway, Eur. J. Mineral., 2009, vol. 21, 11191133.

Wakabayashi, J. and Dilek, Y., What constitutes 'emplacement' of an ophiolite?: Mechanisms and relationship to subduction initiation and formation of metamorphic soles, in Ophiolites in Earth History, Dilek, Y. and Robinson, P. T., Eds., Geol. Soc. Lond. Spec. Publ., 2003, vol. 218, pp. 427447.

Yamamoto, J. and Kagi, H., Application of densimetry using micro-Raman spectroscopy for $\mathrm{CO}_{2}$ fluid inclusions: a probe for elastic strengths of mantle minerals, Eur. J. Mineral., 2008, vol. 20, pp. 529-535.

Yamamoto, Y., Ando, J., Kagi, H., et al., In situ strength measurements on natural upper-mantle minerals, Phys. Chem. Miner., 2008, vol. 35, pp. 249-257.

Yang, J.S., Dobrzhinetskaya, L., Bai, W.B., et al., Diamond- and coesite-bearing chromitites from the Luobusa ophiolite, Tibet, Geology, 2007, vol. 35, no. 10, pp. 875878.

Ye, K., Liu., J.G., Cong, B., and Maruyama, S., Overpressures induced by coesite quartz transitions in zircon, Am Mineral., 2001, vol. 86, no. 10, pp. 1151-1155.

Zhou, M.-F., Robinson, P.T., Malpas, J., and Li, Z., Podiform chromitites in the Luobusa ophiolite (Southern Tibet): Implications for mantle-melt interaction and chromite segregation, J. Petrol., 1996, vol. 37, no. 1, pp. 3-21. 